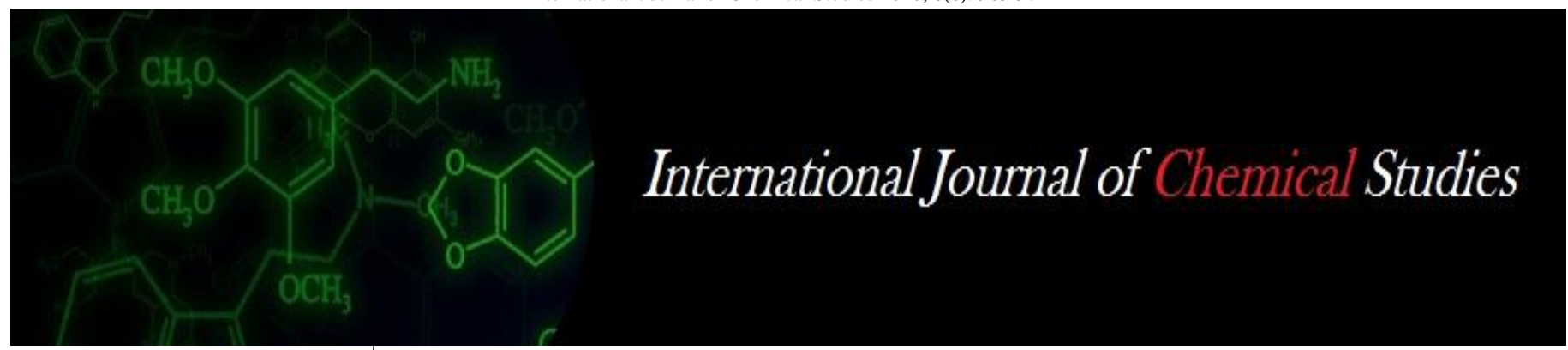

P-ISSN: 2349-8528

E-ISSN: 2321-4902

www.chemijournal.com

IJCS 2020; 8(6): 965-972

(C) 2020 IJCS

Received: 06-09-2020

Accepted: 19-10-2020

Santhosh UN

Department of Agronomy,

University of Agricultural

Sciences, Raichur, Karnataka,

India

Desai BK

Director of Research,

Department of Agronomy,

University of Agricultural

Sciences, Raichur, Karnataka,

India

Satyanarayan Rao

Dean (PGS), Department of

Agronomy, University of

Agricultural Sciences, Raichur,

Karnataka, India

Masthan Reddy BG

Professor (Agronomy),

Department of Agronomy,

University of Agricultural

Sciences, Raichur, Karnataka,

India

Naik MK

Vice Chancellor, UAHS,

Shivamogga, Karnataka, India

Corresponding Author:

Santhosh UN

Department of Agronomy,

University of Agricultural

Sciences, Raichur, Karnataka,

India

\section{Trade-off with tillage, irrigation schedules and novel rice establishment methods implications on soil properties and plant biomass nitrogen chemistry}

\author{
Santhosh UN, Desai BK, Satyanarayan Rao, Masthan Reddy BG and \\ Naik MK
}

DOI: https://doi.org/10.22271/chemi.2020.v8.i6n.10891

\begin{abstract}
Global food security depends on the continued success of rice production. Though rice production has shown a consistent increase, it faces major challenges: The increasing demand for rice versus declining growth in yield and harvested area; soil fertility and productivity decline of intensive rice-based cropping systems resulted from depletion and or limitations of natural resources (soil and water) for rice production. Therefore a field study was conducted for three seasons on a clay loam soil in karnataka, India during Kharif season (2015 \& 2016), Rabi season (2015) to investigate the trade-off with tillage, irrigation schedules and novel rice establishment methods implications on soil properties and plant biomass chemistry. Tillage treatments were Dry (No puddling) and wet tillage (puddling), Establishment methods were Direct seeding (DSR, WSR) and Transplanting (NPTR, PTR), Irrigation treatments were based on soil water tension (SWT) ranging from continuous flooding/saturation (daily irrigation) to alternate wetting and drying (AWD) with irrigation thresholds of 10 and $40 \mathrm{kPa}$ at $18-20 \mathrm{~cm}$ soil depth. The study reveals that among different establishment methods DSR and NPTR under dry tillage (non puddle) condition recorded higher available $\mathrm{N}, \mathrm{P}$ and $\mathrm{K}(\mathrm{kg} / \mathrm{ha})$. Higher Organic carbon $(\mathrm{g} / \mathrm{kg})$, low bulk density, less textural disturbance compared to WSR and PTR under wet tillage (puddled) conditions.
\end{abstract}

Keywords: Dry tillage, wet tillage, establishment methods, irrigation schedules

\section{Introduction}

In India, rice is commonly grown by transplanting seedlings into puddle soil (land preparation with wet tillage). But, repeated puddling adversely affects soil physical properties by destroying soil aggregates, reducing permeability in subsurface layers, and forming hard pans at shallow depths. All of which can negatively affect the following non-rice crop in rotation. Moreover, puddling and transplanting require huge amount of water and labour, both of which are becoming increasingly scarce and expensive, making rice production less profitable.

According to FAO (Food and Agriculture Organization), the global rice requirement by 2025 will be of the order of $800 \mathrm{~m} \mathrm{t}$. At the moment, the production is less than $600 \mathrm{~m} \mathrm{t}$ and hence an additional $200 \mathrm{~m} \mathrm{t}$ needed will have to be produced by increasing productivity per unit area against the diminishing resources. Rice production in Asia is increasingly constrained by water limitation and pressure to reduce water use in irrigated production as a consequence of global water crisis. Asia occupies 60 per cent of world's irrigated fields, half of which are devoted to rice production. Irrigated lowland rice consumes more than 50 per cent of total fresh water, and irrigated flood rice requires two or three times more water than other cereal crops, such as wheat and maize. In addition, rice production is facing increasing competation with rapid urban and industrial development in terms of fresh water resource. The need for "more rice with less water" is crucial for food security, and irrigation plays a greater role in future food needs than it has in the past.

Rice consumes around 27 per cent of the world total fresh water withdrawl (Bouman et al., 2007) ${ }^{[5]}$. For wetland rice production, puddling alone requires 30 per cent of the crop water consumption (Chauhan and Opena, 2012) ${ }^{[7]}$. Predictions indicate that 17-22 $\mathrm{M}$ ha of irrigated rice area in Asia will face water scarcity (Tuong and Bouman, 2002) by 2025, necessitating 
water-saving options to be practiced widely. Manual rice transplanting requires 25-50 persons-day $\mathrm{ha}^{-1}$ (Singh and Sharma, 2012) [17], while the size opf the workforce in agriculture declined due to rapid economic growth in asia in non-agricultural sectors (FICCI, 2015) ${ }^{[9]}$ and increased wages (Zhang et al., 2011) ${ }^{[25]}$.

Production system of Asia is going to undergo adjustments in reaction to rising scarcity of land, water and labor. A major adjustment can be expected in the method of crop organization. Most vital determinants of farmer's choice of crop establishment method are rainfall pattern, weed incidence, field elevation and capability of water supply. The major financial factors like accessibility of labor, wage rates and power for land preparation are considered for the choice of crop establishment technique. In 2025, it is estimated that $15-20 \mathrm{~m}$ ha of irrigated rice will suffer from some degree of water scarcity. Because of depleting ground water resources, global water crisis threatens the sustainability of irrigated rice production. Therefore, a need is being felt for decreasing water use of lowland rice. Large reductions in water inputs can be potentially realized by reducing the unproductive percolation plus seepage losses during crop growth (Bouman and Tuong, 2001) ${ }^{[4]}$.

In India, rice is commonly grown by transplanting seedlings into puddle soil (Land preparation with wet tillage). Puddling benefits rice by reducing water percolation losses, controlling weeds, facilitating easy seedling establishment, and creating anaerobic conditions to enhance nutrient availability. But, repeated puddling adversely affects soil physical properties by destroying soil aggregates, reducing permeability in subsurface layers, and forming hard-pans at shallow depths. All of which can negatively affect the following non-rice upland crop in rotation. Moreover, puddling and transplanting require huge amount of water and labour, both of which are becoming increasingly scarce and expensive, making rice production less profitable. So considering all these things, there is a need to develop appropriate irrigation and tillage method to cope with this problem that will be economically feasible and environmentally sustainable.

Puddling process besides consuming a substantial amount of irrigation water, results in subsurface compaction, which hinders the growth and yield of the succeeding crop. To avoid puddling/transplanting, various resource conservation technologies in rice are being developed and used in IndoGangetic plains. Direct seeding of rice under unpuddled conditions is one such technique which has been shown to be more water efficient, apart from being labour and costeffective. Moreover, it is conducive for mechanization.

Change in rice establishment method from traditional transplanting system to direct-seeding has occurred in Asian rice systems in the last two decades in response to economic factors and technological opportunities in rice farming. Direct-seeding constitutes both wet and dry-seeding and it does away with the need for seedlings, nursery preparation, uprooting of seedlings and transplanting. Research results across India confirmed that dry DSR was advantageous especially during kharif season by providing an opportunity for advancing crop establishment time to make better use of early season rainfall, helps to save irrigation water, higher profit, enable earlier harvest and more timely sowing of succeeding crop after rice Tuong et al. (2000) [21], Balasubramanium and Hill (2002) ${ }^{[2]}$ and Kumar et al. (2015) [13]. During rabi season, Wet seeded rice establishment method prooved promising method because of absence transplanting shock results in better crop establishment, less land preparation time, weed competition less and it reduces the vulnerability to late season drought Gangwar et al. (2005) ${ }^{[10]}$ and Tuong et al. (2005) ${ }^{[23]}$

Solution to all problems can be found in modifications of crop establishment practices (Chakraborty et al., 2017) ${ }^{[8]}$. Among the crop production factors, tillage alone contributes up to 20 per cent of crop production costs (Khurshid et al., 2006) ${ }^{[14]}$ and strongly influences soil properties (Alam et al., 2016). Novel resource -saving technologies are, therefore, being developed to cope growing areas. Mechanical direct-seeding and transplanting under non-puddled/non-flooded conditions have been evaluated as follows.

\section{Material and Methods}

\subsection{Site and soil characteristics}

The study was carried out on the agricultural research station, Gangavathi, India $\left(15^{0} 35^{\prime} \mathrm{N}, 76^{0} 15^{\prime} \mathrm{E}, 419 \mathrm{~m} \mathrm{ASL}\right)$ during 2014 (wet and dry seasons) and 2015 (wet season). The climate is semi arid eco-sub region with a hot summer, wet monsoon season (late June to mid September) and a cool dry winter. Average annual rainfall is $542 \mathrm{~mm}, 85 \%$ of which falls during the monsoon. The soil is medium deep black clay with organic carbon content of $8.25 \mathrm{~g} \mathrm{~kg}^{-1}$ slightly alkaline in reaction ( $\mathrm{pH}$ 8.62). Soil is low in available nitrogen (198.46 $\left.\mathrm{kg} \mathrm{ha}^{-1}\right)$, medium in available phosphorus $\left(59.64 \mathrm{~kg} \mathrm{ha}^{-1}\right)$ and high in available potassium content $\left(369.8 \mathrm{~kg} \mathrm{ha}^{-1}\right)$. The subsoil is clay and overlying clay loam soils. There is a hardpan around $15-25 \mathrm{~cm}$ depth with a bulk density of 1.72 $\mathrm{Mg} \mathrm{m}^{-3}$. The depth of groundwater at the site was around $56 \mathrm{~m}$ and quality of water good for all crops. The site was under a rice-rice cropping system for 5 years prior to establishment of the experiment.

\subsection{Treatment detail and experimental layout}

The experiment was laid out in three replications in a splitsplit plot design with two tillage practices viz., dry tillage (unpuddled) and wet tillage (puddle) in main plots, two establishment methods viz., direct seeding (dry direct seeded rice-DSR, wet direct seeded rice-WSR) and Transplanting (non puddle transplanted rice-NPTR, puddle transplanted rice-PTR) in sub plots and three Irrigation schedules viz., (i) Daily (continuous flooding) and intermittent (generally referred to as AWD treatments) irrigation when the soil water tension (SWT) at $20 \mathrm{~cm}$ depth increased to (ii) $10 \mathrm{kPa}$, (iii) 40 $\mathrm{kPa}$ in sub-sub plots. The daily irrigated treatments were topped up to $50 \mathrm{~mm}$ standing water depth. The amount of irrigation water applied to all AWD treatments was $50 \mathrm{~mm}$ at each irrigation.

\subsection{Tillage and land preparation}

The site was cultivated and laser levelled prior to establishment of the experiment. Plot size was $15 \mathrm{~m} \times 6.2 \mathrm{~m}$. Each plot was demarcated with a plastic lining to prevent seepage. Plastic lining was done before sowing in all experimental individual plots. Around the bunds of all experimental plots $0.6 \mathrm{~m}$ depth plastic lining was made using polythene plastic sheet of thickness $0.5 \mathrm{~mm}$ guage.All the plots were bounded by earthern bunds to prevent lateral movement of water into and through the bunds. There was a $1 \mathrm{~m}$ wide buffer between all sub-plots and the treatments were placed in the same plots each year. For dry tillage soil puddling was replaced by two shallow dry tillage followed bytwo harrowings used both for directly sowing (DSR) and non puddled transplanting (NPTR) taken up. For wet cultivation (WSR and PTR), the land was prepared using 
tractor drawn puddler twice with disc puddler and finally levelled using tractor drawn spike tooth harrow.

\subsection{Crop establishment techniques}

The seed $\left(35 \mathrm{~kg} \mathrm{ha}^{-1}\right)$ was sown in DSR with a four wheel tractor drawn seed drill at a row spacing of $20 \mathrm{~cm}$ and depth of $1-2 \mathrm{~cm}$. on the same day, seed was soaked in water for other treatments. After 24 hour of soaking, the seeds were incubated for 8-10 hour and sown in the wet seeded plots using a drum seeder of four boxes of eight lines at a time with a row spacing of $20 \mathrm{~cm}$, and then in the seedbed for the transplanted treatments. The seed rate was similar for DSR and WSR. Twenty five day old seedlings were transplanted in PTR and NPTR with $30 \times 10 \mathrm{~cm}_{\text {geometry }(2-3 \text { seedlings hill }}$ $\left.{ }^{1}\right)$. For non puddle transplanted rice, light irrigation and drainage of excess water before transplanting was followed

\subsection{Crop management}

The variety used in the investigation was GNV 10-89 (IET7219) medium slender grain type variety suitable for both wet and dry seasons,matures early in about 125-130 days. For direct seeding (DSR and WSR) seed rate of $35 \mathrm{~kg} \mathrm{ha}^{-1}$ was used at a spacing of $20 \mathrm{~cm}$ between rows, whereas for transplanting (NPTR and PTR) seed rate of $62.5 \mathrm{~kg} \mathrm{ha}^{-1}$ used. Twenty five day old seedlings were transplanted in PTR and NPTR with $30 \times 10 \mathrm{~cm}$ geometry (2-3 seedlings hill $\left.{ }^{-1}\right)$. For non puddle transplanted rice, light irrigation and drainage of excess water before transplanting was followed. In DSR and WSR, pendimethalin 30 EC @ 1 kg.a.i/ha at 3 days after sowing was applied as pre emergent followed by bispyribac sodium (10\%) SC @ 35 g.a.i ha ${ }^{-1}$ sprayed at 20 days after sowing (DAS) as early post emergent with the help of hand operated knapsack sprayer. Later two hand weedings at 30 DAS and 50 DAS in DSR and WSR was taken. In PTR and NPTR, six days after transplanting, butachlor $50 \mathrm{EC}$ at the rate of 2.5 lit. ha ${ }^{-1}$ was sand mixed and broadcasted uniformly over the field containing a thin film of water followed by two hand weedings at 20 and 40 days after transplanting (DAT). Fertilizers were applied@ 150:75:75 $\mathrm{kg} \mathrm{ha}^{-1}$ as per the package recommendations. Fifty per cent N, 100 per cent $\mathrm{P}$ and $\mathrm{K}$ was applied at the time of transplanting/sowing in different establishment methods, while remaining 50 per cent $\mathrm{N}$ applied in two equal doses at the time of maximum tillering and panicle initiation stage in all establishment methods At early stage of crop growth to avoid micro nutrient deficiency $\mathrm{ZnSO}_{4} @ 10 \mathrm{~kg} \mathrm{ha}{ }^{-1}$ applied through broadcasting method. Need based plant protection measures were followed with dinitofuron, chlorpyriphos, and propiconazole to control brown plan hoppers, stem borer and neck blast respectively. 2.6 Irrigation water management and soil drying pattern: Irrigation was applied to each plot measured using greyline flow meter. It measures water level and velocity in partially filled pipes and open channels. The instruments works with water level from 1 " to 15 feet. Finally total amount of water used by the crop was calculated based on readings from greyline flow meter and the time taken to irrigate individual plot recorded manually from different irrigation cycles and expressed in $\mathrm{mm} \mathrm{ha}^{-1}$. Flow meter measures velocity, water level and finally records Flow volume $\left(\mathrm{m}^{3} \mathrm{~min}^{-1}\right)$. The amount of irrigation water applied to all irrigation scheduling treatments was $50 \mathrm{~mm}$ at each irrigation cycle. The total amount of irrigation water was calculated from the sum of all irrigations, including pre-tillage and pre-sowing/transplanting irrigations.

\subsection{Soil sampling \& processing}

Representative soil samples from surface $0-5 \mathrm{~cm}, 5-15,15-25$, 25-35 and subsurface samples from $35-45$ and $45-55 \mathrm{~cm}$ were collected from the experimental sites after completion of the experiments. Soil samples were collected separately from each establishment methods of experimental site. The soil samples collected were air dried and passed through a $2 \mathrm{~mm}$ sieve. The processed soil samples were analyzed for selected chemical properties like $\mathrm{pH}$, electrical conductivity (Ec), organic carbon (OC), available $\mathrm{N}, \mathrm{P}$ and $\mathrm{K}$.

\subsection{Soil analysis}

Soil $\mathrm{pH}$ and electric conductivity of the samples were measured on a 1:2.5 soil: water suspension separately using systronic digital $\mathrm{pH}$ meter and Elico digital conductivity meter CM180, respectively. The organic carbon content of soil samples were determined by Walkley and Black (1934) ${ }^{[24]}$ wet oxidation method Available nitrogen was estimated by alkaline potassium permonganate method (Subbiah and Asija, 1956) ${ }^{[19]}$. Available phosphorus was extracted with $0.5 \mathrm{M}$ sodium bicarbonate at $\mathrm{pH} 8.5$ (Olsen's reagent) and amount of phosphorus in the extract was estimated at $820 \mathrm{~nm}$ using spectrophotometer (Elico SL177) as outlined by Jackson (1973) ${ }^{[12]}$.Available potassium was extracted with neutral normal ammonium acetate (Jackson, 1973) [12] and determined using flame photometer (Systronics-128). Particle size distribution of soil samples was determined by the International pipette method as described by Black (1965) ${ }^{[3]}$. Core samples were collected from surface layer from different soil depth layers. Soil samples from the core were dried at 105 ${ }^{\circ} \mathrm{C}$ for 24 hour and cooled in desiccators. Weight of the dried sample was recorded. Volume of the core was measured. Bulk density was calculated with oven dry weight and volume of the soil (Black, 1965) ${ }^{[3]}$.

\subsection{Plant biomass sampling $\&$ analysis}

Plant biomass subsamples collected during flowering and at physiological maturity stage were used for $\mathrm{N}$ determination, the samples were dried at $70{ }^{\circ} \mathrm{C}$ for 2 days then finely ground in willey mill with stainless steel blades and subjected to pass through a $0.5 \mathrm{~mm}$ sieve for nitrate analysis. The ground grain/straw/leaf samples were digested with sulphuric acid digestion mixture $\left(\mathrm{K}_{2} \mathrm{SO}_{4}+\mathrm{CuSO}_{4}+\right.$ selenium powder). The digested sample analysed for total nitrogen content.

2.8 Statistical analysis:

The data collected from different experiments was analyzed statistically by the procedure prescribed by Gomezand Gomez (1984) ${ }^{[11]}$. Critical difference werecalculated at 5\% level wherever ' $F$ ' test was significant.

\section{Results \\ 3.1 Effect on soil physical and chemical properties:}

3.1.1 Soil pH: pH increases as depth of soil samples increases in both dry tillage and wet tillage surface $(0-30 \mathrm{~cm}$ range) and subsurface $(30-55 \mathrm{~cm}$ range) samples also. Soil reactions also varying among different establishment practices. In DSR soil $\mathrm{pH}$ values ranges from 8.14 to 8.52 compared to other establishment methods where soil $\mathrm{pH}$ valueswill range from 8.18 to 8.48 in NPTR, 8.35 to 8.89 in WSR and 8.42 to 8.78 in PTR treatments.

3.1.2 Soil Ec: Electrical conductivity in soil also increases in range as the depth of the soil increases. Ec recorded in ranges of 0.48 to 1.03 in DSR, 0.51 to 0.97 in NPTR, 0.62 to 1.20 in WSR and 0.59 to 1.12 in PTR samples. 
3.1.3 Organic carbon: Soil organic carbon decreases as the depth of soil increasing, organic carbon in soil ranges from 10.23 to $6.42 \mathrm{~g} \mathrm{~kg}^{-1}$ in DSR, 9.85 to $6.87 \mathrm{~g} \mathrm{~kg}^{-1}$ in NPTR, 10.02 to 7.12 in WSR and 9.79 to 7.23 in PTR establishment methods, respectively.

3.1.4 Available $\mathbf{N}\left(\mathbf{k g ~ h a}^{-1}\right)$ : $\mathrm{N}\left(\mathrm{kg} \mathrm{ha}^{-1}\right)$ range high in surface soil samples (0-30 $\mathrm{cm}$ range), as soil depth increases available $\mathrm{N}\left(\mathrm{kg} \mathrm{ha}^{-1}\right)$ also decreases in subsurface soil samples. Available $\mathrm{N}$ ranges from 184.2 to $128.9 \mathrm{~kg} \mathrm{ha}^{-1}$ in DSR, 178.3 to $134.8 \mathrm{~kg} \mathrm{ha}^{-1}$ in NPTR, 162.0 to 102.6 in WSR and 164.5 to 96.8 in PTR soil samples at different depth intervals.

3.1.5 Available $\mathrm{P}\left(\mathrm{kg} \mathrm{ha}^{-1}\right)$ : $\mathrm{P}\left(\mathrm{kg} \mathrm{ha}^{-1}\right)$ also high in surface soil samples $(0-30 \mathrm{~cm}$ range), as soil depth increases available $\mathrm{P}\left(\mathrm{kg} \mathrm{ha}{ }^{-1}\right)$ also decreases in subsurface soil samples. Available P ranges from 174.2 to $109.6 \mathrm{~kg} \mathrm{ha}^{-1}$ in DSR, 165.2 to 65.4 in NPTR, 132.4 to 44.2 in NPTR and 122.8 to $38.6 \mathrm{~kg}$ $\mathrm{ha}^{-1}$ in PTR soil samples.

3.1.6 Available $\mathrm{K}\left(\mathrm{kg} \mathrm{ha}^{-1}\right)$ : $\mathrm{K}$ range also high in surface soil samples (0-30 $\mathrm{cm}$ range), as soil depth increases available $\mathrm{K}$ $\left(\mathrm{kg} \mathrm{ha}^{-1}\right)$ also decreases in subsurface soil samples.Available $\mathrm{K}$ ranges from 372.8 to $256.9 \mathrm{~kg} \mathrm{ha}^{-1}$ in DSR, 372.0 to 251.0 $\mathrm{kg} \mathrm{ha}^{-1}$ in NPTR, 320.0 to $218.6 \mathrm{~kg} \mathrm{ha}^{-1}$ in WSR and 314.2 to $210.2 \mathrm{~kg} \mathrm{ha}^{-1}$ in PTR soil samples.

3.1.7 Soil BD: Higher soil bulk density observed in puddled establishment methods compare to unpuddle establishment methods. Soil bulk density increases upto certain surface depth samples of $25-35 \mathrm{~cm}$ afterwards relatively decreasing trend of soil bulk density observed in paddy soils. Soil bulk density will ranges from 1.25 to $1.39 \mathrm{mg} \mathrm{m}^{-3}$ in DSR, 1.27 to $1.42 \mathrm{mg} \mathrm{m}^{-3}$ in NPTR, 1.54 to $1.74 \mathrm{mg} \mathrm{m}^{-3}$ in WSR and 1.58 to $1.77 \mathrm{mg} \mathrm{m}^{-3}$ in PTR in different soil depth ranges.

3.1.8 Paticle size distribution: The data revealed that total sand, silt and clay content of surface and sub-surface soils in DSR will range from 26 to $28.53,19.0$ to 21.47 and 50.0 to 54.0 per cent and the soil is found to be clay soil in texture in all depth ranges. Similar trend also observed in NPTR soil samples. Whereas, relative increasing percentage of total sand and silt particles observed in puddled soil establishment methods like WSR and PTR samples but here also soil textural class does not varied. Clay soil texture will be major soil component in puddled soil samples also. In WSR total sand, silt and clay content of surface and sub surface soils ranges from 25.5 to $30.18,18.47$ to 26.18 and 47.44 to 51.35 per cent and the soil is found to be clay soil in texture in all depth ranges. Similar trend also observed in PTR soil samples.

\subsection{Plant biomass $\mathrm{N}$ content}

Biomass parts separated during flowering and physiological maturity stages viz., green leaves, dried leaves, stem, panicle and grain samples were analyzed for nitrogen content estimation are presented here

\subsubsection{Nitogen content in green and dried leaves}

Tillage practices had significant influence on nitrogen content in green and dried leaf (\%) at flowering and at harvest. Among tillage practices wet tillage recorded significantly higher nitrogen content during pool of two kharif seasons and pooled over three seasons, respectively) over dry tillage Tillage practices had non-significant influence on nitrogen content in green and dried leaf during rabi season. Similar trend was observed at physiological maturity stage also. Nitogen content in green and leaves (\%) did not differ significantly among effects of different establishment methods. Among irrigation scheduling practices, $10 \mathrm{kPa}$ irrigation treatment recorded significantly higher nitrogen content in green and dried leaves (during pool of two kharif seasons, rabi and pooled over three seasons, respectively at flowering and physiological maturity) and was onpar to continuous flooding irrigation scheduling treatment. Significantly lower nitrogen content in green and dried leaves recorded with $40 \mathrm{kPa}$ irrigation treatment. Interaction effects among tillage, method of establishment and scheduling of irrigation practices on nitrogen content in green and leaves $(\%)$ in flowering and at physiological maturity showed nonsignificant difference.

\subsubsection{Nitogen content in stem and panicle}

Nitrogen content in stem did not differ significantly among tillage practices during rabi season. Whereas, during pool of two kharif seasons and pooled over three seasons significant variations were observed on nitrogen content in stem (\%). Wet tillage recorded significantly higher nitrogen content in stem $(\%)$ at flowering. Similar trend also observed during physiological maturity stage. Effects of method of establishment on nitrogen content in stem (\%) did not differ significantly. Nitrogen content in stem (\%) varied significantly among the scheduling of irrigation practices. 10 $\mathrm{kPa}$ recorded significantly higher nitrogen content in stem $(\%)$ at flowering. Similar trend also observed during physiological maturity stage. Interaction effect of tillage and method of establishment on nitrogen content in stem (\%) was significantly differed only during rabi season. Dry tillage with transplanting recorded significantly higher nitrogen content in stem $(\%)(1.75)$ and was onpar to wet tillage with transplanting (1.68) and wet tillage with direct seeding (1.72) treatment combinations at flowering. Whereas, at physiological maturity stage wet tillage with transplanting recorded significantly higher nitrogen content in stem $(\%)$ (1.38) compare to other treatment combinations.

Significant variation in nitrogen content in panicle $(\%)$ due to tillage practices were observed during pool of two kharif seasons and pooled over three seasons. Wettillage recorded significantly higher nitrogen content in panicle (\%)at flowering. Significantly no differences observed in nitrogen content in panicle (\%) observed in rabi season due to tillage effects. Similar trend also recorded at physiological maturity stage. Nitrogen content in panicle (\%) did not influence significantly due to method of establishment practices. Nitrogen content in panicle $(\%)$ revealed that scheduling of irrigation practices had significant marked variations. $10 \mathrm{kPa}$ recorded significantly higher nitrogen content in panicle (\%) was onpar to continuous flooded treatments. Both these treatments were recorded significantly more nitrogen content in panicle $(\%)$ than $40 \mathrm{kPa}$ treatment at flowering. Similar trend continued at physiological maturity stage. Interaction effect of tillage and method of establishment had significant influence on nitrogen content in panicle (\%) only during rabi season. Dry tillage with transplanting recorded significantly higher nitrogen content in panicle $(\%)(0.75)$ over dry tillage with direct seeding combination $(0.59)$ at flowering. Whereas, at physiological maturity stage wet tillage with transplanting recorded higher nitrogen content in panicle (\%) (1.15) compared to other treatment combinations. Combined interaction effects on nitrogen content in panicle (\%) due to tillage, method of establishment and scheduling of irrigation practices were non significant. 


\subsection{3 $\mathrm{N}$ content in grains}

Nitrogen content in grains found did not differ significantly among establishment methods however, $10 \mathrm{kPa}$ irrigation scheduling recorded significantly higher nitrogen content in grains was onpar to continuous flooded treatment.

\section{Discussion}

\subsection{Effect of tillage, establishment methods and water} management practices on selected soil properties

The growth of any crop depends, to a larger extent on the physical conditions of the soil needed for good root growth, for adequate aeration and water holding. Wet tillage responsible for drastic effects on the physical and chemical soil properties of rice soils. These effects ofen resulted in poor crop establishment leading to very variable yields in the following rice crop. However, rice can also be grown successfully even without puddling in clayey soils. Dry cultivation helps in save the irrigation water required for puddling as well as reducing the bulkdensity and increases hydraulic conductivity of the soil compared to puddled soils. Wet tillage also has its own advantages like residue incorporation, weed suppression and increases availability of soil nutrients. Hence soil properties in rice largely influenced by tillage, crop establishment and water management agronomic practices. This has a direct impact on systems sustainability and crop performance.

Soil $\mathrm{pH}$ and Ec significantly differed with tillage and establishment practices. Soil $\mathrm{pH}$ was ranges near neutral at 0 $35 \mathrm{~cm}$ surface soil 8.14 to 8.67 in DSR, WSR NPTR and PTR methods and was alkaline at $35-45 \mathrm{~cm}$ depth (8.42 to 8.78) in all establishment methods. Soil $\mathrm{pH}$ around slight neutral to alkaline in nature. Soluble salts content in soil as indicated by Ece were less than $4 \mathrm{~d} \mathrm{Sm}^{-1}$ at 0-35 cm depth and $35-45 \mathrm{~cm}$ depth ranges from 0.48 to $0.87 \mathrm{~d} \mathrm{Sm}^{-1}$ and 0.94 to $1.12 \mathrm{~d} \mathrm{Sm}^{-1}$ in DSR, WSR, NPTR and PTR. Slightly alkalinity values of these soils could be attributed due to semi arid climate, presence of basic parent materials. Similar results reported on soils $\mathrm{pH}$ and Ece characters of Gangavathi location by Shashikumar (2015) ${ }^{[13]}$. Soil organic carbon content of surface $(0-35 \mathrm{~cm})$ soils was 10.23 to $8.75 \mathrm{~g} \mathrm{~kg}^{-1}$ and in sub surface samples $(35-55 \mathrm{~cm})$ soils were 7.83 to $6.42 \mathrm{~g} \mathrm{~kg}^{-1}$. The organic carbon content of surface and subsurface soils were found to be high. According to soil fertility ratings given by Tandon (2005) ${ }^{[20]}$. Soil $\mathrm{pH}$ ranges 8.14 to 8.52 slight to neutral in dry tillage compare to 8.35 to 8.89 slight alkaline in wet tillage practices.

Nitrogen availability in dry tillage in surface and subsurface soils samples ranges from (184.2 to $134.8 \mathrm{~kg} \mathrm{ha}^{-1}$ ) and in wet tillage it ranges from (162 to $\left.96.8 \mathrm{~kg} \mathrm{ha}^{-1}\right)$. At all depths in both tillage methods the availability $\mathrm{N}$ status is low as per soil fertility ratings $\left(<280 \mathrm{~kg} \mathrm{ha}^{-1}\right)$ (Tandon, 2005) ${ }^{[20]}$. Slightly higher available $\mathrm{N}$ status observed in dry tillage compare to wet tillage. Similarly soil available P and K status of this soil were considered as high in ratings as soil fertility ratings given by Tandon (2005) ${ }^{[20]}$. Soil available $\mathrm{P}_{2} \mathrm{O}_{5}$ and $\mathrm{K}_{2} \mathrm{O}$ status also high in range in dry tillage compare to wet tillage. Regarding soil bulk density $\left(\mathrm{mg} \mathrm{m}^{-3}\right)$ increases slightly upto certain depth and in sub-surface soils slightly in decreasing trend. Dry tillage recorded significantly lowest soil bulk density and soil bulk density values higher in puddled wet lands. Among particle size distribution at different depths soils observed as clay soil in both dry and wet tillage systems. Only difference slight sand: silt: clay ratios varies in puddle we tillage. Although the soil found to be clay in nature even after changes in depths. Similar results also reported by Srinivasa Prasad (2015) ${ }^{[18]}$ on soil properties of wet and dry tillage practices.

\subsection{Plant biomass nitrogen chemistry}

Under Pudled wet tillage condition, Nitrogen content is high in different accumulated biomass parts like green leaf, dried leaf, stem, panicle at flowering stage and green leaf, dried leaf, stem, panicle and grains at physiological maturity stage of the crop. Higher nitrogen content might due to significant higher content of SPAD cholorophyll value and NDVI values during crop growth stages. Higher cholorophyll and NDVI values due to better leaf area and availability of nutrients, water and energy offered by wet tillage resulting in opportunity for greater root growth, increased availability and accessibility of nutrients. Such report were also made by Chander and Pandey (2001) ${ }^{[6]}$ and Singh and Singh (2006) [16].

Table 1: Selective soil properties of dry direct seeded rice (DSR) at different soil depths during end of third crop

\begin{tabular}{|c|c|c|c|c|c|c|c|c|c|c|c|}
\hline \multirow[b]{2}{*}{$\begin{array}{c}\text { Soil } \\
\text { depth } \\
(\mathrm{cm})\end{array}$} & \multirow[b]{2}{*}{$\begin{array}{c}\text { Soil } \\
\text { pH } \\
(1: 2.5)\end{array}$} & \multirow{2}{*}{$\begin{array}{c}\text { Soil } \\
\text { Ec } \\
(\mathbf{d s} \\
\left.\mathbf{m}^{-1}\right)\end{array}$} & \multirow[b]{2}{*}{$\begin{array}{c}\text { Organic } \\
\text { carbon } \\
\left(\mathrm{g} \mathrm{kg}^{-1}\right)\end{array}$} & \multirow[b]{2}{*}{$\begin{array}{c}\text { Available } \\
\mathbf{N} \\
\left(\mathrm{kg} \mathrm{ha}^{-1}\right)\end{array}$} & \multirow[b]{2}{*}{$\begin{array}{c}\text { Available } \\
\mathbf{P} \\
\left(\mathrm{kg} \mathrm{ha}^{-1}\right)\end{array}$} & \multirow[b]{2}{*}{$\begin{array}{c}\text { Available } \\
\text { K } \\
\left(\mathrm{kg} \mathrm{ha}^{-1}\right)\end{array}$} & \multirow[b]{2}{*}{$\begin{array}{c}\text { Soil bulk } \\
\text { density } \\
\left(\mathrm{mg} \mathrm{m}^{-3}\right)\end{array}$} & \multicolumn{4}{|c|}{ Particle size distribution (\%) } \\
\hline & & & & & & & & $\begin{array}{l}\text { Total } \\
\text { sand }\end{array}$ & Silt & Clay & $\begin{array}{c}\text { Soil } \\
\text { textural } \\
\text { class }\end{array}$ \\
\hline $0-5$ & 8.14 & 0.48 & 10.23 & 184.2 & 174.2 & 372.8 & 1.25 & 28.53 & 21.47 & 50 & Clay \\
\hline $5-15$ & 8.22 & 0.52 & 9.80 & 176.2 & 154.3 & 365.5 & 1.28 & 28.27 & 19.26 & 52.47 & Clay \\
\hline $15-25$ & 8.28 & 0.67 & 9.61 & 164.5 & 136.8 & 332.6 & 1.35 & 27 & 19 & 54 & Clay \\
\hline $25-35$ & 8.34 & 0.87 & 7.83 & 158.7 & 127.7 & 301.4 & 1.39 & 27 & 20 & 53 & Clay \\
\hline $35-45$ & 8.42 & 0.94 & 7.46 & 138.6 & 115.4 & 278.5 & 1.27 & 26 & 21 & 53 & Clay \\
\hline $45-55$ & 8.52 & 1.03 & 6.42 & 128.9 & 109.6 & 256.9 & 1.29 & 26 & 20 & 54 & Clay \\
\hline
\end{tabular}

Table 2: Selective soil properties of non puddle transplanted rice (NPTR) at different soil depths during end of third crop

\begin{tabular}{|c|c|c|c|c|c|c|c|c|c|c|c|}
\hline \multirow{2}{*}{$\begin{array}{c}\text { Soil depth } \\
(\mathrm{cm})\end{array}$} & \multirow{2}{*}{$\begin{array}{l}\text { Soil pH } \\
(1: 2.5)\end{array}$} & \multirow{2}{*}{\multicolumn{2}{|c|}{\begin{tabular}{|l|c|}
$\begin{array}{l}\text { Soil Ec } \\
\left(\mathrm{ds} \mathrm{m}^{-1}\right)\end{array}$ & Organic carbon \\
$\left(\mathrm{g} \mathrm{kg}^{-1}\right)$
\end{tabular}}} & \multirow{2}{*}{\multicolumn{2}{|c|}{$\begin{array}{c}\text { Available N Available P } \\
\left(\mathrm{kg} \mathrm{ha}^{-1}\right)\end{array}$}} & \multirow{2}{*}{$\begin{array}{c}\text { Available K } \\
\left(\mathrm{kg} \mathrm{ha}^{-1}\right)\end{array}$} & \multirow{2}{*}{$\begin{array}{c}\text { Soil bulk density } \\
\left(\mathrm{mg} \mathrm{m}^{-3}\right)\end{array}$} & \multicolumn{4}{|c|}{ Particle size distribution (\%) } \\
\hline & & & & & & & & Total sand & d Silt & Clays & textural class \\
\hline $0-5$ & 8.18 & 0.51 & 9.85 & 178.3 & 165.2 & 372 & 1.27 & 26.48 & 16.72 & 56.8 & Clay \\
\hline $5-15$ & 8.23 & 0.57 & 9.42 & 175.4 & 158.6 & 367.8 & 1.29 & 26 & 17 & 57 & Clay \\
\hline $15-25$ & 8.31 & 0.63 & 9.21 & 168.5 & 128.7 & 342.5 & 1.37 & 26 & 18 & 56 & Clay \\
\hline $25-35$ & 8.4 & 0.71 & 8.42 & 158.7 & 98.9 & 310 & 1.42 & 25 & 19 & 56 & Clay \\
\hline $35-45$ & 8.44 & 0.82 & 7.56 & 142.3 & 86.5 & 284 & 1.32 & 25 & 19 & 57 & Clay \\
\hline $45-55$ & 8.48 & 0.97 & 6.87 & 134.8 & 65.4 & 251 & 1.26 & 24 & 21 & 55 & Clay \\
\hline
\end{tabular}


Table 3: Selective soil properties of wet seeded rice (WSR) at different soil depths during end of third crop

\begin{tabular}{|c|c|c|c|c|c|c|c|c|c|c|c|}
\hline \multirow{3}{*}{\multicolumn{3}{|c|}{\begin{tabular}{|c|c|c|}
$\begin{array}{c}\text { Soil depth } \\
\text { (cm) }\end{array}$ & $\begin{array}{c}\text { Soil pH } \\
(\mathbf{1 : 2 . 5})\end{array}$ & $\begin{array}{c}\text { Soil Ec } \\
\left(\mathbf{d s ~ m}^{-1}\right)\end{array}$ \\
$0-5$ & 8.35 & 0.62 \\
\end{tabular}}} & \multirow{3}{*}{\begin{tabular}{c|}
$\begin{array}{c}\text { Organic carbon } \\
\left(\mathrm{g} \mathrm{kg}^{-1}\right)\end{array}$ \\
10.02 \\
\end{tabular}} & \multirow{3}{*}{$\begin{array}{c}\begin{array}{c}\text { Available I } \\
\left(\text { kg ha }^{-1}\right)\end{array} \\
162\end{array}$} & \multirow{3}{*}{\begin{tabular}{|c|}
$\begin{array}{c}\text { Available P } \\
\text { (kg ha }^{-1} \text { ) }\end{array}$ \\
132.4 \\
\end{tabular}} & \multirow{3}{*}{\begin{tabular}{|c|}
$\begin{array}{c}\text { Available K } \\
\text { (kg ha-1 })\end{array}$ \\
320 \\
\end{tabular}} & \multirow{3}{*}{$\begin{array}{c}\begin{array}{c}\text { Soil bulk density } \\
\left(\mathbf{m g ~ m}^{-3}\right)\end{array} \\
1.54 \\
\end{array}$} & \multicolumn{4}{|c|}{ Particle size distribution (\%) } \\
\hline & & & & & & & & Total sand & Silt & Clay $\mathbf{S}$ & Soil textural class \\
\hline & & & & & & & & 30.18 & 18.47 & 51.35 & Clay \\
\hline $5-15$ & 8.42 & 0.67 & 9.87 & 154.5 & 121.4 & 314.6 & 1.62 & 27.39 & 24.02 & 48.59 & Clay \\
\hline $15-25$ & 8.48 & 0.78 & 8.54 & 146.8 & 118.6 & 282 & 1.67 & 26.38 & 26.18 & 47.44 & Clay \\
\hline $25-35$ & 8.56 & 0.89 & 7.62 & 132.5 & 88.7 & 254.2 & 1.74 & 27.34 & 21.43 & 51.23 & Clay \\
\hline $35-45$ & 8.68 & 0.94 & 7.26 & 118.4 & 69.8 & 236.5 & 1.66 & 26.66 & 24 & 49.34 & Clay \\
\hline $45-55$ & 8.89 & 1.2 & 7.12 & 102.6 & 44.2 & 218.6 & 1.62 & 25.5 & 25.76 & 48.74 & Clay \\
\hline
\end{tabular}

Table 4: Selective soil properties of puddle transplanted rice (PTR) at different soil depths during end of third crop

\begin{tabular}{|c|c|c|c|c|c|c|c|c|c|c|c|}
\hline \multirow[b]{2}{*}{$\begin{array}{c}\text { Soil } \\
\text { depth } \\
(\mathrm{cm})\end{array}$} & \multirow[b]{2}{*}{$\begin{array}{c}\begin{array}{c}\text { Soil } \\
\text { pH } \\
(1: 2.5)\end{array} \\
\end{array}$} & \multirow{2}{*}{$\begin{array}{c}\text { Soil } \\
\text { Ec } \\
(d s \\
\left.m^{-1}\right)\end{array}$} & \multirow[b]{2}{*}{$\begin{array}{l}\text { Organic } \\
\text { carbon } \\
\left(\mathrm{g} \mathrm{kg}^{-1}\right)\end{array}$} & \multirow[b]{2}{*}{$\begin{array}{c}\text { Available } \\
\qquad \begin{array}{c}\mathbf{N} \\
\left(\mathrm{kg} \mathrm{ha}^{-1}\right)\end{array}\end{array}$} & \multirow[b]{2}{*}{$\begin{array}{c}\text { Available } \\
\mathbf{P} \\
\left(\mathrm{kg} \mathrm{ha}^{-1}\right)\end{array}$} & \multirow[b]{2}{*}{$\begin{array}{c}\text { Available } \\
\text { K } \\
\left(\mathrm{kg} \mathrm{ha}^{-1}\right)\end{array}$} & \multirow[b]{2}{*}{$\begin{array}{c}\text { Soil bulk } \\
\text { density } \\
\left(\mathrm{mg} \mathrm{m}^{-3}\right)\end{array}$} & \multicolumn{4}{|c|}{ Particle size distribution (\%) } \\
\hline & & & & & & & & $\begin{array}{l}\text { Total } \\
\text { sand }\end{array}$ & Silt & Clay & $\begin{array}{c}\text { Soil } \\
\text { textural } \\
\text { class }\end{array}$ \\
\hline $0-5$ & 8.42 & 0.59 & 9.79 & 164.5 & 122.8 & 314.2 & 1.62 & 30.62 & 17 & 52.38 & Clay \\
\hline $5-15$ & 8.47 & 0.63 & 9.54 & 158.7 & 117.4 & 309.2 & 1.64 & 26.66 & 24 & 49.34 & Clay \\
\hline $15-25$ & 8.58 & 0.72 & 9.13 & 144.6 & 103.5 & 302.8 & 1.68 & 25.5 & 25.76 & 48.74 & Clay \\
\hline $25-35$ & 8.67 & 0.87 & 8.75 & 122.3 & 77.6 & 262.6 & 1.77 & 22.77 & 19.43 & 57.8 & Clay \\
\hline $35-45$ & 8.72 & 0.95 & 7.73 & 102.6 & 54.2 & 232.4 & 1.66 & 23.57 & 18.9 & 57.53 & Clay \\
\hline $45-55$ & 8.78 & 1.12 & 7.23 & 96.8 & 38.6 & 210.2 & 1.58 & 21.39 & 20.47 & 58.14 & Clay \\
\hline
\end{tabular}

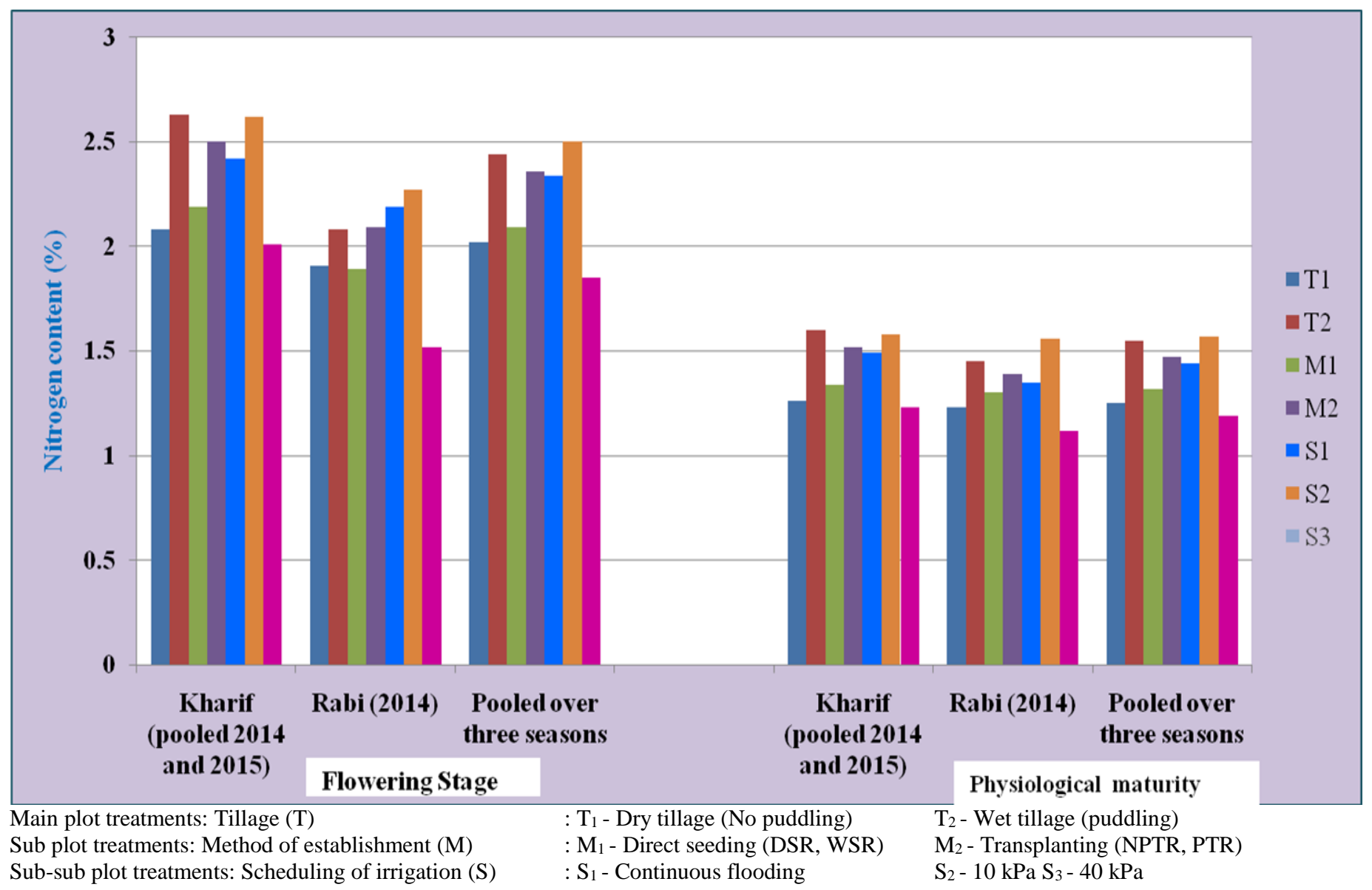

Fig 1: Nitrogen content in green leaves (\%) at flowering and physiological maturity stage of rice as influenced by tillage, crop establishment methods and water management practices during kharif (pooled 2014 and 2015), rabi (2014) and data pooled over three seasons 


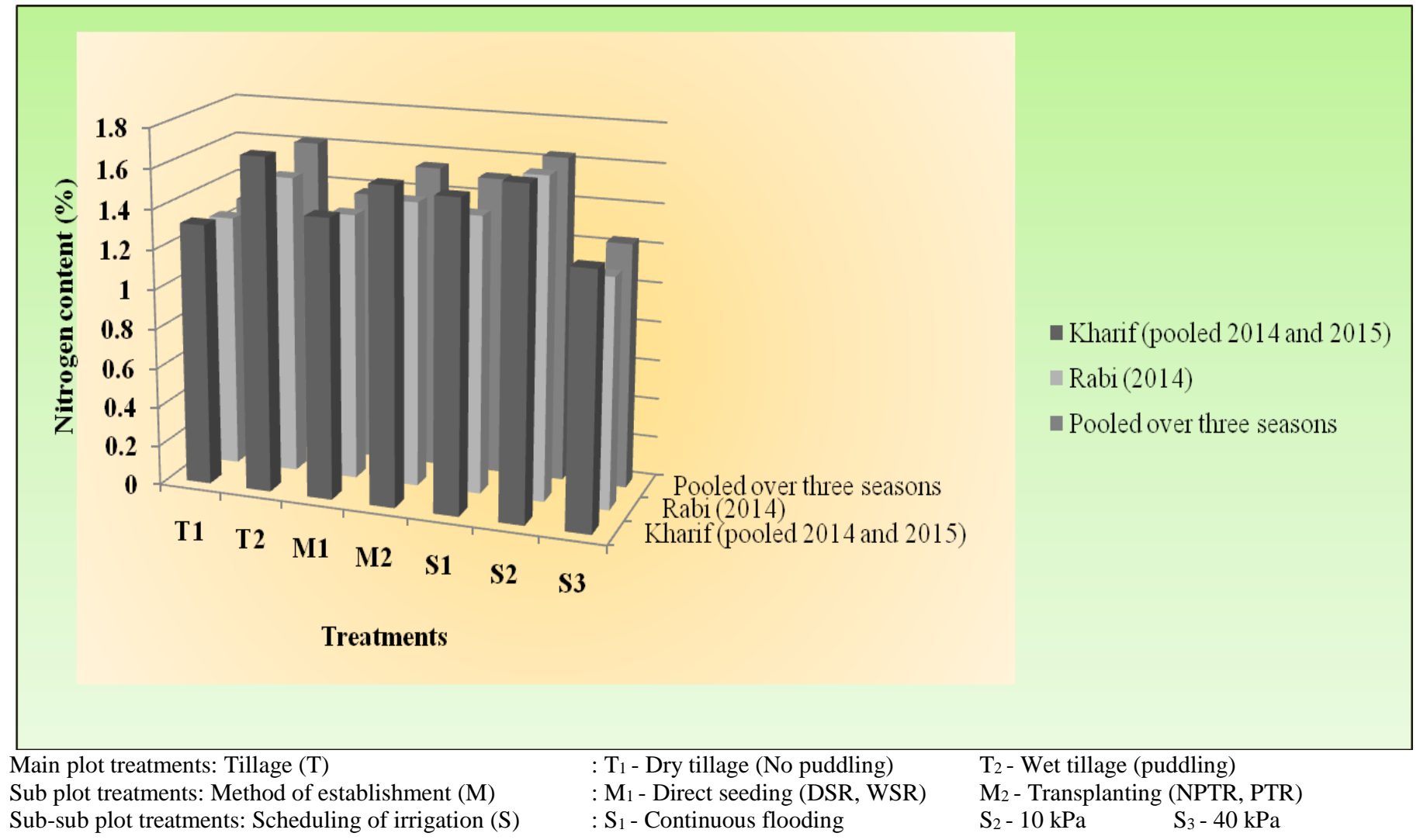

Fig 2: Nitrogen content in grains $(\%)$ at physiological maturity stage of rice as influenced by tillage, crop establishment methods and water management practices during kharif (pooled 2014 and 2015), rabi (2014) and data pooled over three seasons

\section{Conclusion}

Non -puddled dry tillage system reduced the negative effects of agricultural intensification on soil properties. However, knowledge of long-term impacts of non-puddled systems on soil properties is insufficient. Dry tillage system modified soil physical and chemical properties, mainly in the surface layers $(0-25 \mathrm{~cm})$ showed higher organic OC, available N,P,K alkaline to neutral soil reaction, low bulk density and less textural disturbance compared to traditional puddle wet tillage rice production system.

\section{Acknowledgement}

This study was a part of the $\mathrm{PhD}$ thesis research of the senior author. The technical and financial support provided by the International Rice Research Institute under Global rice science partnership (GRiSP) Program. University authority extends thanks to Dr. Sudhir Yadav, Lead-Soil, Climate and Water and Senior Scientist - Water management, International Rice Research Institute, Manila, Philippines for serving as Advisor and rendering all technical support.

\section{References}

1. Alam MK, Islam MM, Salahin N, Hasanuzzaman M, Effect of tillage practices on soil properties andcrop productivity in wheat-mungbean-rice cropping system under subtropical climatic conditions. Sci. World J 2014;10:40-55.

2. Balasubramanian V, Hill JE. Direct seeding of rice in Asia: Emerging issues and strategic research needs for the $21^{\text {st }}$ century. In Direct seeding: Research strategies and opportunities, (Pandey S. ed.) IRRI, Los Banos, Philippines 2002, 15-39.

3. Black CA. Methods of soil analysis, Part-1, Agron. J., Madison, USA 1965, 770.
4. Bouman BAM, Tuong TP. Field water management to save water and increase its productivity in irrigated lowland rice. Agric. Water Manage 2001;49:11-30.

5. Bouman BAM, Lampayan RM, Tuong TP. Water Management in Irrigated Rice: Coping with Water Scarcity; International Rice Research Institute: Los Baños, Philippines 2007, 1-54.

6. Chander S, Pandey. Effect of rice culture, nitrogen and weed control on nitrogen competition between scented rice and weeds. Indian J. Agron 2001;46(1):68-74.

7. Chauhan BS, Opeña J. Effect of tillage systems and herbicides on weed emergence, weed growth, and grainyield in dry-seeded rice systems. Field Crops Res., 2012;137:56-69.

8. Chakraborty D, Ladha JK, Rana DS, Jat ML, Gathala MK, Yadav $\mathrm{S}$ et al. A global analysis of alternative tillage and crop establishment practices for economically andenvironmentally efficient rice production. Sci. Rep. 2017;7:9342.

9. FICCI (Federation of Indian Chambers of Commerce \& Industry). Labour in Indian Agriculture: A GrowingChallenge. 2015. Available online: http://ficci.in/spdocument/20550/FICCI-agri-

Report\%2009-03-2015.pdf(accessed on 18 May 2016).

10. Gangwar KS, Sharma, Tomar OK, Pandey DK. Effect of rice crop establishment methods on hybrid rice productivity in northwest India. International Rice Research Notes 2005;30:42-43.

11. Gomez KA, Gomez AA. Statistical procedures for agricultural research. $2^{\text {nd }} \mathrm{Ed}$, Wiley Inter Science, New York 1984,

12. Jackson ML. Soil Chemical Analysis. Oxford IBH Publishing House, Bombay 1973, 38. 
13. Kumar A, Kumar S, Dahiya K, Kumar S, Kumar M. Productivity and economics of direct seeded rice (Oryza sativa L.). J. Appl. Nat. Sci 2015;7(1): 410-416.

14. Khurshid K, Iqbal M, Arif MS, Nawaz A. Effect of tillage and mulch on soil physical properties andgrowth of maize. Int. J. Agric. Biol. 2006;8:593-596.

15. Shashikumar KV. Studies on water and nutrient management of dry direct seeded rice (Oryza sativa L.). M.Sc. (Agri) thesis, Univ. of Agri. Sci., Raichur, India 2015, 1-128.

16. Singh P, Singh SS. Effect of crop establishment method, fertility level and weed management practices on aromatic rice (Oryza sativa L.). Indian J. Agron 2006; 51(4):288-292.

17. Singh S, Sharma AK. Gender issues for drudgery reduction and sustainable small holder farming in rice production system. J. Hill Agric 2012;3:99-102.

18. Srinivasa Prasad L. Studies on soil quality parameters of selected dry direct seeded and puddled paddy fields of Agroclimatic Zone 2 and 3 of Karnataka. M.Sc. (Agri) thesis submitted to Univ. of Agri. Sci., Raichur, India, 2015, 1-154.

19. Subbaiah BV, Asija GL. A rapid procedure for the estimation of available nitrogen in soils. Curr. Sci 1956;25:259-260.

20. Tandon HLS. Methods of analysis of soils, plants, waters, fertilizers and organic manures. Fertilizer development and consultation organization, New Delhi, India 2005; 1 140.

21. Tuong TP, Singh AK, Siopongco J, Wade LJ. Constraints to high yield of dry seeded rice in the rainy season in a humid tropic environment. Plant Prod. Sci., 2000;3:164172.

22. Tuong TP, Bouman BAM. Rice Production in Water Scarce Environments in Water Productivity in Agriculture: Limits and Opportunities for Improvement; Kijne, J.W., Barker, R., Molden, D., Eds.; CABI Publishing: Wallingford, UK, 2002, 13-42.

23. Tuong TP, Bouman BAM, Mortimer M. More rice, less water - Integrated approaches for increasing water productivity in irrigated rice based systems in Asia. Plant Prod. Sci 2005;8:231-241.

24. Walkley A, Black IA. An examination of Degttjareff method for determining soil organic matter and proposal modifications of the chromic acid titration method. Soil Sci 1934,37:29-38.

25. Zhang W, Yu Y, Huang Y, Li T, Wang P. Modelling methane emissions from irrigated rice cultivation in China from 1960 to 2050.Glob. Chang. Biol 2011;17:3511-3523. 